\title{
CYP24A1 wt Allele
}

National Cancer Institute

\section{Source}

National Cancer Institute. CYP24A1 wt Allele. NCI Thesaurus. Code C104147.

Human CYP24A1 wild-type allele is located within 20q13.2-q13.3 and is approximately 21

$\mathrm{kb}$ in length. This allele, which encodes 1,25-dihydroxyvitamin $D(3)$ 24-hydroxylase,

mitochondrial protein, is involved in vitamin D3 metabolism and calcium homeostasis.

Mutations in CYP24A1 are associated with infantile hypercalcemia. 